\title{
Mucilaginibacter boryungensis sp. nov., isolated from soil
}

Correspondence

Jung-Hoon Yoon

jhyoon@kribb.re.kr

\author{
So-Jung Kang, † Yong-Taek Jung, † Ki-Hoon Oh, Tae-Kwang Oh \\ and Jung-Hoon Yoon
}

Korea Research Institute of Bioscience and Biotechnology (KRIBB), PO Box 115, Yusong, Taejon, Korea

\begin{abstract}
A Gram-stain-negative, non-motile, non-spore-forming bacterial strain, BDR- $9^{\top}$, was isolated from soil collected from Boryung on the west coast of the Korean peninsula, and its taxonomic position was investigated by using a polyphasic study. Strain BDR $-9^{\top}$ grew optimally at $25{ }^{\circ} \mathrm{C}$, at $\mathrm{pH}$ 6.0-7.5 and in the absence of $\mathrm{NaCl}$. Phylogenetic analyses based on 16S rRNA gene sequences revealed that strain BDR- $9^{\top}$ fell within the clade comprising species of the genus Mucilaginibacter within the phylum Bacteroidetes. 16S rRNA gene sequence similarity values between strain BDR- $9^{\top}$ and the type strains of species of the genus Mucilaginibacter were in the range $94.0-95.6 \%$. Strain $B D R-9^{\top}$ contained $\mathrm{MK}-7$ as the predominant menaquinone and iso- $\mathrm{C}_{15: 0}$ and $\mathrm{C}_{16: 1} \omega 7 \mathrm{c}$ and/or iso- $\mathrm{C}_{15: 0} 2-\mathrm{OH}$ as the major fatty acids. The DNA G+C content was $44.3 \mathrm{~mol} \%$. Differential phenotypic properties and phylogenetic distinctiveness of strain BDR $-9^{\top}$ demonstrated that this strain is distinguishable from species of the genus Mucilaginibacter. On the basis of phenotypic, chemotaxonomic and phylogenetic data, strain BDR $-9^{T}$ is considered to represent a novel species of the genus Mucilaginibacter, for which the name Mucilaginibacter boryungensis sp. nov. is proposed. The type strain is BDR- $9^{\top}$

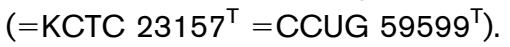

The genus Mucilaginibacter was first proposed by Pankratov et al. (2007) through the descriptions of two novel species, Mucilaginibacter paludis and Mucilaginibacter gracilis. Subsequently, five further species with validly published names, Mucilaginibacter kameinonensis (Urai et al., 2008), Mucilaginibacter daejeonensis (An et al., 2009), Mucilaginibacter ximonensis (Luo et al., 2009), Mucilaginibacter oryzae (Jeon et al., 2009) and Mucilaginibacter rigui (Baik et al., 2010), were described. Phylogenetic analysis based on 16S rRNA gene sequences showed that the genus Mucilaginibacter forms an evolutionary lineage within the phylum Bacteroidetes (Pankratov et al., 2007). Members of the genus Mucilaginibacter have been isolated from peat bogs, soil, dried rice straw and wetland freshwater (Pankratov et al., 2007; Urai et al., 2008; An et al., 2009; Baik et al., 2010). In the study, we report the taxonomic characterization of a Mucilaginibacter-like bacterial strain, BDR-9 ${ }^{\mathrm{T}}$, which was isolated from soil collected from Boryung on the west coast of the Korean peninsula.

Strain BDR $-9^{\mathrm{T}}$ was isolated by means of the standard dilution plating technique at $25{ }^{\circ} \mathrm{C}$ on $\mathrm{R} 2 \mathrm{~A}$ agar (Difco). The type strains of four species of the genus Mucilaginibacter

†These authors contributed equally to this work.

The GenBank/EMBL/DDBJ accession number for the 16S rRNA gene sequence of strain BDR-9 ${ }^{\top}$ is HM061614. were used as reference strains for phenotypic characterization and fatty acid analysis. M. paludis KACC $13450^{\mathrm{T}}$ and $M$. oryzae KACC $12816^{\mathrm{T}}$ were obtained from the Korean Agricultural Culture Collection (KACC), Suwon, South Korea. M. kameinonensis KCTC $22227^{\mathrm{T}}$ and M. ximonensis KCTC $22437^{\mathrm{T}}$ were obtained from the Korean Collection for Type Cultures (KCTC), Taejon, South Korea. The morphological, physiological and biochemical characteristics of strain BDR $-9^{\mathrm{T}}$ were investigated using routine cultivation on R2A agar at $25{ }^{\circ} \mathrm{C}$. Cell morphology was examined by using light microscopy (E600; Nikon) and transmission electron microscopy (CM-20; Philips). Flagellation was determined by using transmission electron microscopy on cells from an exponentially growing culture. For this purpose, the cells were negatively stained with $1 \%(\mathrm{w} / \mathrm{v})$ phosphotungstic acid and the grids were examined after being air-dried. Gliding motility was investigated as described by Bowman (2000). The Gram reaction was determined by using the bioMérieux Gram stain kit according to the manufacturer's instructions. Growth in the absence of $\mathrm{NaCl}$ and in the presence of 0.5 , $1.0,2.0$ and $3.0 \%(\mathrm{w} / \mathrm{v}) \mathrm{NaCl}$ was investigated by using R2A broth prepared according to the formula of the Difco medium except that agar was excluded. Growth at 4, 15, 20, $25,28,30,37$ and $40{ }^{\circ} \mathrm{C}$ was measured on $\mathrm{R} 2 \mathrm{~A}$ agar. The $\mathrm{pH}$ range for growth was determined in $\mathrm{R} 2 \mathrm{~A}$ broth adjusted to $\mathrm{pH} 4.0-9.5$ in increments of $0.5 \mathrm{pH}$ units by the addition of $\mathrm{HCl}$ or $\mathrm{Na}_{2} \mathrm{CO}_{3}$. Growth under anaerobic conditions was 
Table 1. Differential phenotypic characteristics of strain BDR $-9^{\top}$ and some phylogenetically related species of the genus Mucilaginibacter

Strains: 1, M. boryungensis sp. nov. BDR-9 $9^{\mathrm{T}}$; 2, M. kameinonensis KCTC $22227^{\mathrm{T}}$; 3, M. oryzae KACC $12816^{\mathrm{T}}$; 4 , M. ximonensis KCTC $22437^{\mathrm{T}}$. All data from this study except for flexirubin-type pigments, oxidase and DNA G + C content; these data from Urai et al. (2008), Jeon et al. (2009) and Luo et al. (2009). +, Positive reaction; -, negative reaction; w, weakly positive reaction. All strains are Gram-stain-negative and rod-shaped. All strains are positive for hydrolysis of aesculin, utilization of D-xylose, galactose, glucose, mannose and maltose, and activity of leucine arylamidase, acid phosphatase, $\alpha$-galactosidase (weak for M. kameinonensis KCTC $22227^{\mathrm{T}}$ ), $\beta$-galactosidase (weak for M. kameinonensis KCTC $22227^{\mathrm{T}}$ ) and $N$ acetyl- $\beta$-glucosaminidase. All species are negative for motility, utilization of erythritol, D-arabinose, ribose, L-xylose, sorbose, dulcitol, inositol, mannitol, amygdalin, inulin, xylitol, D-lyxose, D-tagatose, D-fucose, D-arabitol, L-arabitol, 2-ketogluconate and 5-ketogluconate, and activity of esterase (C4), lipase (C14), cystine arylamidase, trypsin, $\alpha$-chymotrypsin and $\beta$-glucuronidase.

\begin{tabular}{|c|c|c|c|c|}
\hline Characteristic & 1 & 2 & 3 & 4 \\
\hline Colony colour on R2A agar & Light yellow & Pale yellow & Light pink & Yellow \\
\hline Flexirubin-type pigments & + & + & - & - \\
\hline Oxidase & - & - & + & + \\
\hline \multicolumn{5}{|l|}{ Utilization of: } \\
\hline Glycerol & - & + & - & - \\
\hline L-Arabinose & + & + & + & - \\
\hline Adonitol & + & - & - & - \\
\hline$\beta$-Methyl D-xyloside & - & + & + & - \\
\hline Fructose & - & + & + & + \\
\hline Rhamnose & + & + & + & - \\
\hline Sorbitol & - & - & - & + \\
\hline$\alpha$-Methyl D-mannoside & - & + & + & + \\
\hline$\alpha$-Methyl D-glucoside & - & + & + & + \\
\hline$N$-Acetylglucosamine & - & + & + & + \\
\hline Arbutin & - & + & + & - \\
\hline Aesculin & - & + & + & + \\
\hline Salicin & - & + & - & - \\
\hline Cellobiose & - & + & + & + \\
\hline Lactose & + & + & + & - \\
\hline Melibiose & - & + & + & + \\
\hline Sucrose & - & + & + & + \\
\hline Trehalose & - & + & + & + \\
\hline Melezitose & - & + & + & + \\
\hline Raffinose & - & + & + & + \\
\hline Starch & - & + & + & - \\
\hline Glycogen & - & + & + & - \\
\hline Gentiobiose & + & + & - & - \\
\hline Turanose & - & + & + & + \\
\hline L-Fucose & - & + & - & - \\
\hline Gluconate & - & + & + & - \\
\hline \multicolumn{5}{|l|}{ Enzyme activity (API ZYM) } \\
\hline Alkaline phosphatase & + & - & + & + \\
\hline Esterase lipase (C8) & - & $\mathrm{w}$ & - & - \\
\hline Valine arylamidase & - & - & $\mathrm{w}$ & - \\
\hline Naphthol-AS-BI-phosphohydrolase & + & - & - & - \\
\hline$\alpha$-Glucosidase & - & + & + & + \\
\hline$\beta$-Glucosidase & - & + & + & - \\
\hline$\alpha$-Mannosidase & - & - & - & + \\
\hline$\alpha$-Fucosidase & - & - & - & + \\
\hline DNA G $+C$ content $(\mathrm{mol} \%)$ & 44.3 & 43.7 & 44.4 & 43.4 \\
\hline
\end{tabular}

determined after incubation in a Forma anaerobic chamber on $\mathrm{R} 2 \mathrm{~A}$ agar and on $\mathrm{R} 2 \mathrm{~A}$ agar supplemented with potassium nitrate $(0.1 \%, w / v)$, both of which had been prepared anaerobically under a nitrogen atmosphere. Catalase and oxidase activities were determined as described by Cowan \&
Steel (1965). Hydrolysis of casein, starch, hypoxanthine, tyrosine and xanthine was tested on R2A agar by using the substrate concentrations described by Cowan \& Steel (1965). Nitrate reduction and hydrolysis of aesculin, gelatin, Tweens $20,40,60$ and 80 and urea were investigated as described by 
Lányí (1987). $\mathrm{H}_{2} \mathrm{~S}$ production was tested as described by Bruns et al. (2001). Susceptibility to antibiotics was tested on R2A agar plates using antibiotic discs (Advantec) containing the following: polymyxin B (100 U), streptomycin $(50 \mu \mathrm{g})$, penicillin $\mathrm{G}(20 \mathrm{U})$, chloramphenicol $(100 \mu \mathrm{g})$, ampicillin $(10 \mu \mathrm{g})$, cephalothin $(30 \mu \mathrm{g})$, gentamicin $(30 \mu \mathrm{g})$, novobiocin $(5 \mu \mathrm{g})$, tetracycline $(30 \mu \mathrm{g})$, kanamycin $(30 \mu \mathrm{g})$, lincomycin $(15 \mu \mathrm{g})$, oleandomycin $(15 \mu \mathrm{g})$, neomycin $(30 \mu \mathrm{g})$ and carbenicillin $(100 \mu \mathrm{g})$. Utilization of various substrates, enzyme activities and other physiological and biochemical properties were tested by using the API $20 \mathrm{E}$, API $50 \mathrm{CH}$ and API ZYM systems (bioMérieux); utilization of various substrates was determined by inoculating the API $50 \mathrm{CH}$ strip with cells suspended in AUX medium (bioMérieux). The presence of flexirubin-type pigments was investigated as described by Reichenbach (1992). Morphological, cultural, physiological and biochemical characteristics of strain BDR$9^{\mathrm{T}}$ are given in the species description or in Table 1.

Cell biomass of strain BDR- $9^{\mathrm{T}}$ for DNA extraction and for isoprenoid quinone analysis was obtained from cultures grown for 3 days at $25{ }^{\circ} \mathrm{C}$ in $\mathrm{R} 2 \mathrm{~A}$ broth prepared according to the formula of the Difco medium except that agar was excluded. Chromosomal DNA was isolated and purified according to the method described by Yoon et al. (1996), with the exception that RNase T1 was used in combination with RNase A to minimize contamination with RNA. The 16S rRNA gene was amplified by PCR using two universal primers as described previously (Yoon et al., 1998). Sequencing of the amplified 16S rRNA gene and phylogenetic analysis were performed as described by Yoon et al. (2003). The almost complete 16S rRNA gene sequence of strain BDR-9 ${ }^{\mathrm{T}}$ determined in this study comprised $1445 \mathrm{nt}$ (approx. $96 \%$ of the Escherichia coli 16S rRNA sequence). In the neighbour-joining phylogenetic tree based on $16 \mathrm{~S}$ rRNA gene sequences, strain BDR- $9^{\mathrm{T}}$ fell within the cluster comprising species of the genus Mucilaginibacter (Fig. 1). Strain BDR-9 ${ }^{\mathrm{T}}$ exhibited 94.0-95.6\% $16 \mathrm{~S}$ rRNA gene sequence similarity to the type strains of species of the genus Mucilaginibacter, including species without validly published names at the time of writing, and less than $91.6 \%$ to the other species used in the phylogenetic analysis. The DNA G $+\mathrm{C}$ content was determined by the method of Tamaoka \& Komagata (1984) with the modification that DNA was hydrolysed and the resultant nucleotides were analysed by reversed-phase HPLC. The DNA G + C content of strain BDR- $9^{\mathrm{T}}$ was $44.3 \mathrm{~mol} \%$.

Isoprenoid quinones were extracted according to the method of Komagata \& Suzuki (1987) and analysed using reversed-phase HPLC and a YMC ODS-A $(250 \times 4.6 \mathrm{~mm})$ column. The predominant isoprenoid quinone detected in strain BDR-9 ${ }^{\mathrm{T}}$ was menaquinone-7 (MK-7), which is the same as that found in members of the genus Mucilaginibacter (Pankratov et al., 2007; Urai et al., 2008; An et al., 2009; Luo et al., 2009; Jeon et al., 2009). For fatty acid methyl ester analysis, cell mass of strain BDR- $9^{\mathrm{T}}$ and the type strains of four species of the genus Mucilaginibacter was harvested from R2A agar after incubation for 3 days at $25{ }^{\circ} \mathrm{C}$. Fatty acid methyl esters were extracted and prepared according to the standard protocol of the MIDI/Hewlett Packard Microbial Identification System (Sasser, 1990). Cellular fatty acid profiles of strain BDR- $9^{\mathrm{T}}$ and the type strains of the four species of the genus Mucilaginibacter analysed in this study are shown in Table 2 . The major fatty acids ( $>10 \%$ of total fatty acids) found in strain BDR- $9^{\mathrm{T}}$ were iso- $\mathrm{C}_{15: 0}$ and $\mathrm{C}_{16: 1} \omega 7 c$ and/or iso- $\mathrm{C}_{15: 0}$ 2-OH (Table 2 ). The fatty acid profiles of the five strains were similar, although there were differences in the proportions of some fatty acids (Table 2). The fatty acid profiles of the four reference strains were also similar to those analysed previously (Pankratov et al., 2007; Urai et al., 2008; Luo

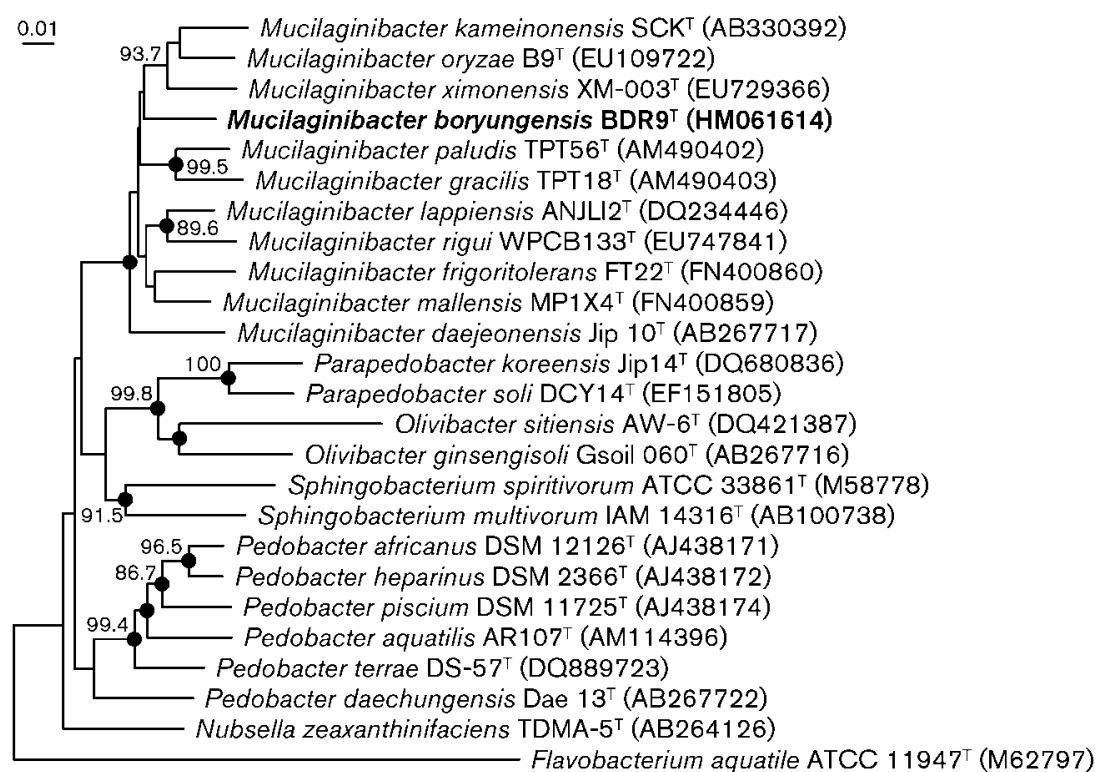

http://ijs.sgmjournals.org
Fig. 1. Neighbour-joining phylogenetic tree based on 16S rRNA gene sequences showing the positions of strain BDR-9 ${ }^{\top}$, other species of the genus Mucilaginibacter and some other related taxa. Bootstrap values (expressed as percentages of 1000 replications) $>70 \%$ are shown at branching points. Filled circles indicate that the corresponding nodes were also recovered in trees generated with the maximum-likelihood and maximum-parsimony algorithms. Flavobacterium aquatile ATCC $11947^{\top}$ (GenBank accession no. M62797) was used as an outgroup. Bar, 0.01 substitutions per nucleotide position. 
Table 2. Cellular fatty acid compositions (\%) of strain BDR $-9^{\top}$ and the type strains of some species of the genus Mucilaginibacter

Strains: 1 , M. boryungensis sp. nov. BDR- $9^{\mathrm{T}} ; 2$, M. paludis KACC $13450^{\mathrm{T}}$; 3, M. kameinonensis KCTC $22227^{\mathrm{T}}$; 4, M. oryzae KACC $12816^{\mathrm{T}}$; 5, M. ximonensis KCTC $22437^{\mathrm{T}}$. All data from this study. Fatty acids that represented $<0.5 \%$ in all strains were omitted. - , Not detected.

\begin{tabular}{|c|c|c|c|c|c|}
\hline Fatty acid & 1 & 2 & 3 & 4 & 5 \\
\hline \multicolumn{6}{|c|}{ Straight-chain fatty acid } \\
\hline $\mathrm{C}_{14: 0}$ & 0.4 & 0.9 & 2.1 & 1.3 & 0.4 \\
\hline $\mathrm{C}_{15: 0}$ & 9.3 & 6.0 & - & 3.9 & 3.7 \\
\hline $\mathrm{C}_{16: 0}$ & 1.1 & 5.3 & 11.5 & 8.0 & 3.9 \\
\hline \multicolumn{6}{|l|}{ Branched fatty acid } \\
\hline iso- $\mathrm{C}_{15: 0}$ & 28.3 & 22.6 & 21.0 & 18.8 & 37.9 \\
\hline anteiso- $\mathrm{C}_{15: 0}$ & 1.5 & 13.5 & - & - & 0.6 \\
\hline iso- $\mathrm{C}_{16: 0}$ & 1.0 & 0.4 & - & - & 0.1 \\
\hline iso- $\mathrm{C}_{17: 0}$ & 0.2 & - & - & - & 0.9 \\
\hline iso- $\mathrm{C}_{17: 1} \omega 9 c$ & 4.2 & 0.6 & - & 2.5 & 5.0 \\
\hline \multicolumn{6}{|c|}{ Unsaturated fatty acid } \\
\hline $\mathrm{C}_{15: 1} \omega 6 c$ & 5.0 & 1.3 & - & 1.1 & 1.8 \\
\hline $\mathrm{C}_{16: 1} \omega 5 c$ & 1.5 & 5.1 & 4.0 & 4.2 & 3.5 \\
\hline $\mathrm{C}_{17: 1} \omega 6 c$ & 0.6 & 0.5 & - & - & 0.2 \\
\hline $\mathrm{C}_{17: 1} \omega 8 c$ & 2.2 & 0.7 & - & 0.9 & 0.44 \\
\hline \multicolumn{6}{|l|}{ Hydroxy fatty acid } \\
\hline $\mathrm{C}_{15: 0} 2-\mathrm{OH}$ & 0.8 & 1.0 & - & - & 0.3 \\
\hline $\mathrm{C}_{15: 0} 3-\mathrm{OH}$ & 0.6 & - & - & - & 0.7 \\
\hline $\mathrm{C}_{16: 0} 3-\mathrm{OH}$ & 0.9 & 1.4 & 11.0 & 5.7 & 2.1 \\
\hline $\mathrm{C}_{17: 0} 2-\mathrm{OH}$ & 0.4 & 0.6 & - & - & - \\
\hline $\mathrm{C}_{17: 0} 3-\mathrm{OH}$ & 0.8 & 0.7 & - & - & 0.2 \\
\hline iso- $\mathrm{C}_{15: 0} 3-\mathrm{OH}$ & 2.3 & 1.5 & - & 2.2 & 1.9 \\
\hline iso- $\mathrm{C}_{17: 0} 3-\mathrm{OH}$ & 9.1 & 8.8 & 10.8 & 11.4 & 9.2 \\
\hline \multicolumn{6}{|l|}{ Summed features ${ }^{\star}$} \\
\hline 3 & 24.5 & 26.8 & 39.7 & 39.4 & 25.2 \\
\hline 5 & 2.3 & - & - & - & - \\
\hline \multicolumn{6}{|c|}{ Unknown fatty acids $\dagger$} \\
\hline ECL 13.565 & 0.3 & 1.0 & - & 0.8 & 0.5 \\
\hline ECL 16.582 & 0.8 & 0.5 & - & - & 0.8 \\
\hline
\end{tabular}

* Summed features represent groups of two or three fatty acids which could not be separated by GLC with the MIDI system. Summed feature 3 contained $\mathrm{C}_{16: 1} \omega 7 c$ and/or iso- $\mathrm{C}_{15: 0}$ 2-OH. Summed feature 5 contained $\mathrm{C}_{18: 2} \omega 6,9 c$ and/or anteiso- $\mathrm{C}_{18: 0}$.

${ }^{\dagger} \mathrm{ECL}$, Equivalent chain-length.

et al., 2009; Jeon et al., 2009). The results obtained from chemotaxonomic analyses, showing the properties that are shared by species of the genus Mucilaginibacter, were in agreement with the result of the phylogenetic analysis, i.e. that strain BDR- $9^{\mathrm{T}}$ belongs to the genus Mucilaginibacter (Pankratov et al., 2007; Urai et al., 2008; An et al., 2009; Luo et al., 2009; Jeon et al., 2009).

Strain BDR- $9^{\mathrm{T}}$ was distinguishable from phylogenetically related species of the genus Mucilaginibacter by differences in several phenotypic characteristics, most of which were determined in this study under the same conditions (Table 1). The phylogenetic distinctiveness of strain BDR- $9^{\mathrm{T}}$, together with the differential phenotypic properties, is sufficient to demonstrate that this strain is separate from other species of the genus Mucilaginibacter (Stackebrandt \& Goebel, 1994). Therefore, on the basis of the data presented, strain BDR- $9^{\mathrm{T}}$ is considered to represent a novel species of the genus Mucilaginibacter, for which the name Mucilaginibacter boryungensis sp. nov. is proposed.

\section{Description of Mucilaginibacter boryungensis sp. nov.}

Mucilaginibacter boryungensis (bo.ry.ung.en'sis. N.L. masc. adj. boryungensis pertaining to Boryung, from where the type strain was isolated).

Cells are Gram-staining-negative, non-spore-forming, non-flagellated rods $(0.4-0.6 \times 1.0-6.0 \mu \mathrm{m})$. Colonies on R2A agar are circular to slightly irregular, slightly convex, smooth, glistening, light yellow and $2.0-3.0 \mathrm{~mm}$ in diameter after incubation for 5 days at $25{ }^{\circ} \mathrm{C}$. Optimal growth occurs at $25{ }^{\circ} \mathrm{C}$; grows at 4 and 37 (weakly) ${ }^{\circ} \mathrm{C}$, but not at $40{ }^{\circ} \mathrm{C}$. Optimal $\mathrm{pH}$ for growth is between 6.0 and 7.5; grows at $\mathrm{pH} 4.5$ and 8.5 , but not at $\mathrm{pH} 4.0$ or 9.0. Optimal growth occurs in the absence of $\mathrm{NaCl}$; growth occurs with $0-0.5 \%(\mathrm{w} / \mathrm{v}) \mathrm{NaCl}$. Growth occurs under anaerobic conditions on R2A and on R2A supplemented with nitrate. Aesculin, starch, tyrosine and Tweens 20, 40, 60 and 80 are hydrolysed, but casein, hypoxanthine, xanthine and urea are not. Flexirubin-type pigments are produced. Susceptible to chloramphenicol, gentamicin, lincomycin, neomycin, oleandomycin, streptomycin and tetracycline, but not to ampicillin, carbenicillin, cephalothin, kanamycin, novobiocin, penicillin $\mathrm{G}$ or polymyxin B. The predominant menaquinone is MK-7. The major fatty acids ( $>10 \%$ of total fatty acids) are iso- $\mathrm{C}_{15: 0}$ and $\mathrm{C}_{16: 1} \omega 7 c$ and/or iso- $\mathrm{C}_{15: 0} 2-\mathrm{OH}$. The DNA G $+\mathrm{C}$ content is $44.3 \mathrm{~mol} \%$ (HPLC). Other phenotypic properties are shown in Table 1.

The type strain, BDR $-9^{\mathrm{T}}\left(=\right.$ KCTC $23157^{\mathrm{T}}=$ CCUG $\left.59599^{\mathrm{T}}\right)$, was isolated from soil around the coast at Boryung, Korea.

\section{Acknowledgements}

This work was supported by the Program for Collection, Management and Utilization of Biological Resources (grant M10867010003) and the 21C Frontier Program of Microbial Genomics and Applications (grant MG05-0401-2-0) from the Ministry of Education, Science and Technology (MEST) of the Republic of Korea.

\section{References}

An, D.-S., Yin, C.-R., Lee, S.-T. \& Cho, C.-H. (2009). Mucilaginibacter daejeonensis sp. nov., isolated from dried rice straw. Int J Syst Evol Microbiol 59, 1122-1125.

Baik, K. S., Park, S. C., Kim, E. M., Lim, C. H. \& Seong, C. N. (2010). Mucilaginibacter rigui sp. nov., isolated from wetland freshwater, and emended description of the genus Mucilaginibacter. Int J Syst Evol Microbiol 60, 134-139. 
Bowman, J. P. (2000). Description of Cellulophaga algicola sp. nov., isolated from the surfaces of Antarctic algae, and reclassification of Cytophaga uliginosa (ZoBell and Upham 1944) Reichenbach 1989 as Cellulophaga uliginosa comb. nov. Int J Syst Evol Microbiol 50, 1861-1868.

Bruns, A., Rohde, M. \& Berthe-Corti, L. (2001). Muricauda ruestringensis gen. nov., sp. nov., a facultatively anaerobic, appendaged bacterium from German North Sea intertidal sediment. Int J Syst Evol Microbiol 51, 1997-2006.

Cowan, S. T. \& Steel, K. J. (1965). Manual for the Identification of Medical Bacteria. London: Cambridge University Press.

Jeon, Y., Lee, S.-S., Chung, B. S., Kim, J. M., Bae, J.-W., Park, S. K. \& Jeon, C. O. (2009). Mucilaginibacter oryzae sp. nov., isolated from soil of a rice paddy. Int J Syst Evol Microbiol 59, 1451-1454.

Komagata, K. \& Suzuki, K. (1987). Lipid and cell wall analysis in bacterial systematics. Methods Microbiol 19, 161-207.

Lányí, B. (1987). Classical and rapid identification methods for medically important bacteria. Methods Microbiol 19, 1-67.

Luo, X., Zhang, L., Dai, J., Liu, M., Zhang, K., An, H. \& Fang, C. (2009). Mucilaginibacter ximonensis sp. nov., isolated from Tibetan soil. Int J Syst Evol Microbiol 59, 1447-1450.

Pankratov, T. A., Tindall, B. J., Liesack, W. \& Dedysh, S. N. (2007). Mucilaginibacter paludis gen. nov., sp. nov. and Mucilaginibacter gracilis sp. nov., pectin-, xylan- and laminarin-degrading members of the family Sphingobacteriaceae from acidic Sphagnum peat bog. Int J Syst Evol Microbiol 57, 2349-2354.
Reichenbach, H. (1992). The order Cytophagales. In The Prokaryotes, 2nd edn, vol. 4, pp. 3631-3675. Edited by A. Balows, H. G. Trüper, M. Dworkin, W. Harder \& K. H. Schleifer. New York: Springer.

Sasser, M. (1990). Identification of bacteria by gas chromatography of cellular fatty acids. Technical Note 101. Newark, DE: MIDI, Inc.

Stackebrandt, E. \& Goebel, B. M. (1994). Taxonomic note: a place for DNA-DNA reassociation and $16 \mathrm{~S}$ rRNA sequence analysis in the present species definition in bacteriology. Int J Syst Bacteriol 44, 846849.

Tamaoka, J. \& Komagata, K. (1984). Determination of DNA base composition by reverse-phase high-performance liquid chromatography. FEMS Microbiol Lett 25, 125-128.

Urai, M., Aizawa, T., Nakagawa, Y., Nakajima, M. \& Sunairi, M. (2008). Mucilaginibacter kameinonensis sp. nov., isolated from garden soil. Int J Syst Evol Microbiol 58, 2046-2050.

Yoon, J.-H., Kim, H., Kim, S.-B., Kim, H.-J., Kim, W. Y., Lee, S. T., Goodfellow, M. \& Park, Y.-H. (1996). Identification of Saccharomonospora strains by the use of genomic DNA fragments and rRNA gene probes. Int J Syst Bacteriol 46, 502-505.

Yoon, J.-H., Lee, S. T. \& Park, Y.-H. (1998). Inter- and intraspecific phylogenetic analysis of the genus Nocardioides and related taxa based on 16S rDNA sequences. Int J Syst Bacteriol 48, 187-194.

Yoon, J.-H., Kim, I.-G., Shin, D.-Y., Kang, K. H. \& Park, Y.-H. (2003). Microbulbifer salipaludis sp. nov., a moderate halophile isolated from a Korean salt marsh. Int J Syst Evol Microbiol 53, 53-57. 